\title{
Monetary Equivalents
}

Selected amounts of money (referred to in the text by *) and their value today (2002) to the nearest pound/dollar. Note: in pre-decimal British currency $12 \mathrm{~d}=$ one shilling (1s) and 20 shillings $=£ 1$. On decimalization (15 February 1971) one shilling became 5 p. Therefore (for example) $£ 1212 \mathrm{~s}=£ 12.60$ and $18 \mathrm{~s}=90 \mathrm{p}$.

\begin{tabular}{|c|c|c|c|}
\hline Date & Amount & $\begin{array}{c}\text { UK Sterling } \\
\text { today }\end{array}$ & $\begin{array}{c}\text { US Dollars } \\
\text { today }\end{array}$ \\
\hline 7 April, 1900 & $£ 1212 \mathrm{~s}$ & $£ 786$ & $\$ 1270$ \\
\hline 22 April, 1900 & $£ 2710$ s $6 \mathrm{~d}$ & $£ 1717$ & $\$ 2790$ \\
\hline 5 December, 1903 & $£ 2000$ & $£ 123482$ & $\$ 193000$ \\
\hline 4 October, 1904 & $£ 7$ & $£ 440$ & $\$ 670$ \\
\hline 14 June, 1910 & $£ 1000$ & $£ 62394$ & $\$ 89800$ \\
\hline 10 January, 1913 & $£ 115 \mathrm{~s} 4 \mathrm{~d}$ & $£ 107$ & $\$ 152$ \\
\hline end of January 1915 & 600 crowns & $£ 913$ & $\$ 1640$ \\
\hline 25 August, 1915 & $£ 75$ & $£ 3531$ & $\$ 6350$ \\
\hline 22 February, 1917 & $£ 200$ & $£ 6310$ & $\$ 13300$ \\
\hline 13 June, 1917 & $2 \mathrm{~s} 6 \mathrm{~d}$ & $£ 4$ & $\$ 8$ \\
\hline 14 May, 1919 & $£ 5000$ & $£ 137522$ & $\$ 225000$ \\
\hline 30 May, 1919 & $\$ 700$ & $£ 4428$ & $\$ 7270$ \\
\hline 14 September, 1920 & 20000 lire & $£ 6391$ & $\$ 8910$ \\
\hline 21 February, 1921 & $\$ 50$ & $£ 393$ & $\$ 502$ \\
\hline 20 March, 1922 & $£ 8500$ & $£ 313208$ & $\$ 397000$ \\
\hline 12 July, 1923 & $£ 21000$ & $£ 753858$ & $\$ 1000000$ \\
\hline 14 January, 1924 & $\$ 1975$ & $£ 16184$ & $\$ 20800$ \\
\hline September, 1925 & $\$ 200$ & $£ 1524$ & $\$ 2040$ \\
\hline 3 June, 1928 & $\$ 11000$ & $£ 96427$ & $\$ 115000$ \\
\hline 18 March, 1930 & $£ 200$ & $£ 9726$ & $\$ 10200$ \\
\hline 29 December, 1931 & $£ 100$ & $£ 5409$ & $\$ 5370$ \\
\hline 2 March, 1932 & 60000 francs & $£ 39748$ & $\$ 31100$ \\
\hline 11 November, 1932 & 4000 francs & $£ 2650$ & $\$ 2070$ \\
\hline 19 November, 1934 & $£ 4000$ & $£ 225964$ & $\$ 268000$ \\
\hline 3 August, 1938 & 1000 francs & $£ 280$ & $\$ 366$ \\
\hline 10 August, 1939 & $18 \mathrm{~s}$ & $£ 46$ & $\$ 51$ \\
\hline 14 October, 1940 & $£ 30$ & $£ 1081$ & $\$ 1470$ \\
\hline
\end{tabular}

